\title{
TINJAUAN YURIDIS PENERAPAN UPAH TENAGA KONTRAK PERUSAHAAN DAERAH AIR MINUM (PDAM)TIRTA INDRAGIRI BERDASARKAN KEPUTUSAN GUBERNUR RIAU Nomor: \\ Kpts. 1058/XI/ 2016 tentang Upah \\ Minimum Kabupaten/Kota \\ Se Provinsi Riau \\ Tahun 2017
}

SKRIPSI

Diajukan Sebagai Salah Satu Syarat

Untuk Memperoleh Gelar Sarjana Hukum (SI)

Pada Fakultas Hukum Universitas Islam Indragiri

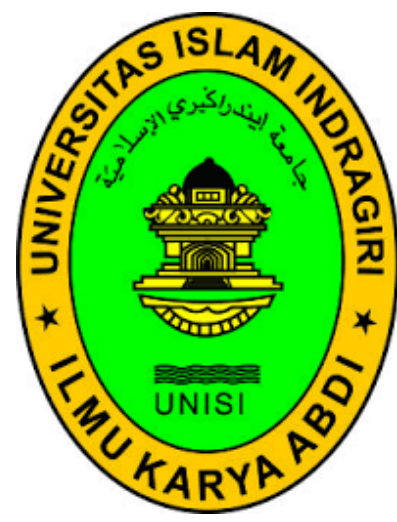

Oleh :

MURSALIN

NIM : 30110110063

FAKULTAS HUKUM

UNIVERSITAS ISLAM INDRAGIRI

TAHUN 2017 


\title{
TINJAUAN YURIDIS PENERAPAN UPAH TENAGA KONTRAK PERUSAHAAN DAERAH AIR MINUM (PDAM) TIRTA INDRAGIRI BERDASARKAN KEPUTUSAN GUBERNUR RIAU Nomor:KPTS.1058/IX/2016Tentang Upah Minimum Kabupaten/Kota Se Provinsi Riau Tahun 2017.
}

\author{
Oleh : MURSALIN
}

Pembimbing : Wandi, SH., MH dan KMS. Novyar Satriawan, SH., MH

\section{ABSTRAK}

Konstruksi hukum dalam ketentuan Pasal 28D ayat (2) Undang-Undang Dasar 1945 memberi suatu deskriptif bahwa "Setiap orang berhak untuk bekerja serta mendapat imbalan dan perlakuan yang adil dan layak dalam hubungan kerja", dalam Pasal 88 ayat (1) Undang-Undang Nomor. 13 tahun 2003 tentang ketenagakerjaan, bahwa "Setiap pekerja berhak memperoleh penghasilan yang memenuhi penghidupan yang layak bagi kemanusiaan.

Perumusan masalah dalam penulisan ini 1) Tinjauan yuridis kebijakan dinas tenaga kerja kabupaten indragiri hilir dalam penerapan upah tenaga kontrak perusahaan daerah air minum tirta indragiri berdasarkan keputusan Gubernur Riau Nomor: Kpts.1058/XI/2016 tentang upah minimum kabupaten/kota se provinsi riau tahun 2017. 2) Kendala dan Upaya Kebijakan Dinas Tenaga Kerja Kabupaten Indragiri Hilir Dalam Penerapan Upah Tenaga Kontrak Perusahaan Daerah Air Minum Tirta Indragiri berdasarkan Keputusan Gubernur Riau Nomor: Kpts.1058/XI/2016 tentang Upah Minimum Kabupaten/Kota Se Provinsi Riau Tahun 2017.

Jenis penelitian penulisan skripsi ini adalah penelitian hukum empiris sosiologis dengan menggunakan data primer yang diperoleh langsung di lapangan melalui masyarakat atau responden. sifatnya, penulisan ini bersifat deskriptif yaitu memberikan gambaran disertai penjelasan secara sistematik, faktual dan akurat, Analisis data adalah analisis kualitatif yaitu data yang diperoleh dari responden baik tertulis maupun lisan dipelajari sebagai sesuatu yang utuh dan berkualitas, kemudian disusun secara sistematis agar dapat kejelasan masalah yang akan dibahas. Hasilnya diolah dan disajikan dengan cara membandingkan antara data lapangan dengan pendapat ahli atau dengan peraturan perundang-undangan yang dijadikan dasar yuridis dalam pokok masalah. Kemudian menarik kesimpulan penulis menggunakan dengan cara deduktif yakni penarikan kesimpulan dari hal yang bersifat umum menuju hal yang bersifat khusus.

Dapat disimpulkan yaitu:1) Kebijakan upah minimum Kabupaten merupkan kebijakan yang wajib ditaati oleh setiap perusahaan di Indonesia, termasuk semua perusahaan di Kabupaten Indragiri Hilir. Upah Minimum Kabupaten setiap daerah berbeda-beda tergantung sumber daya manusia, potensi dan kemajuan ekonomi serta daya saing suatu daerah dengan daerah lain. 2) kendala-kendalanya, kurang pengawasan yang di lakukan oleh Pemda mengenai penerapan UMK. Upaya, pelaksanaan pengawasan terhadap pemenuhan upah minimum akan menjamin hak pekerja, mendidik pengusaha dan para pekerja agar selalu menaati ketentuan perundang-undangan di bidang ketenagakerjaan sehingga kepastian hukum, keadilan dan kemanfaatan yang diinginkan dapat tercapai. 


\section{DAFTAR PUSTAKA}

\section{A. Buku-Buku}

Asri Wijayanti, 2010, Hukum Ketenagakerjaan Pasca Reformasi, Sinar Grafika, Cetakan Pertama, Jakarta.

Bambang Sanggono, 1998, Metodologi Penelitian Hukum, Cetakan kedua, Penerbit Raja Grafindo Persada, Jakarta.

Budi Winarno, 2007, Analisis Kebijakan Publik, Pustaka Pelajar, Yogyakarta.

Budi Winarno, 2007, Sistem Politik Indonesia Era Repormasi, Gren Media Pustaka Utama, Jakarta.

Deliarnov, 2000, Perkembangan Pemikiran Ekonomi, Jakarta:Raja Grapindo Perkasa.

Gitosudarmo, 1995, Dasar-dasar Pembelanjaan Perusahaan, Edisi Keempat Cetakan, Pertama, Yogyakarta

Handoko, 1993, Manajemen Personalia \& Sumberdaya Manusia, Edisi Pertama, BPFE UGM Yogyakarta.

Hardijan Rusli, 2003, Hukum Ketenagakerjaan, Jakarta Ghalia Indonesia.

Hasibuan, 1999, Manajemen Sumber Daya Manusia, Jakarta: PT Bumi. Aksara.

Jimly Asshiddiqie, 2006, Hukum Tata Negara dan Pilar-pilar Demokrasi, Serpihan Pemikiran Hukum, Media dan HAM, Cetakan Kedua, Konstitusi Press, Jakarta.

Koesoemahatmadja, 1999, Pengantar Ke Arah Sistem Pemerintahan Daerah Di Indonesia, PT. Bina Cipta, Bandung. 
Lalu Husni, 2000, Pengantar Hukum Ketenagakerjaan Indonesia, Jakarta, Raja Grafindo Persada.

Lalu Husni, 2010, Hukum Ketenagakerjaan Indonesia Edisi Revisi, Rajawali Pers, Jakarta.

Lalu Husni, 2001, Pengantar Hukum Ketenagakerjaan Indonesia, PT. Raja, Grafindo Persada, Jakarta.

Leo Agustino, 2003, Dasar-Dasar Kebijakan Publik, Alfabed, Bandung.

Maria Farida Indrati S, 2007, Ilmu Peundang-Undangan, cetakan I, PT. Subur, Yogyakarta.

Marom Chairul, 2002, Sistem Akuntansi Perusahaan Dagang, Jakarta: PT, Grafindo.

Matul Huda, 2005, Otonomi Daerah Filosofi, Sejarah Perkembangan dan Problematika, Cetakan I, Yogyakarta.

Miriam Budiardjo, 1998, Dasar-Dasar Ilmu Politik, Jakarta: Gramedia Pustaka Utama.

Moeljatno, 2007, Politik Pembangunan : Sebuah Analisis Konsep, Arah dan Strategi, PT. Tiara Wacana Yogya, Yogyakarta.

Morison, 2005, Hukum Tata Negara Era Reformasi, Ramdina Prakarsa, Jakarta.

Pusat Bahasa Departemen Pendidikan Nasional, 2001, Kamus Besar Bahasa Indonesia, Balai Pustaka, Jakarta.

Rachman, Maman, 1999, Strategidan Langkah-Langkah Penelitian, Semarang: IKIP Semarang Press. 
Rianto Adi, 2005, Metodologi Penelitian Sosial dan Hukum, Granit, Jakarta.

Ridwan, HR, 2006, Hukum Administrasi Negara, Raja Grafindo Persada, Jakarta.

Ronny Hanitijo Soemitro, 1990, Metodologi Penelitian Hukum dan Jurimetri. Ghlmia Indonesia, Jakarta.

Sendjun H. Manulang, Pokok-Pokok Hukum Ketenagakerjaan Di Indonesia, Jakarta, Rhineka Cipta, 2001, Hlm. 3

Soetrisno Hadi, Metodologi Reseacrh Jilid II, Yogyakarta : Yayasan Penerbit Fakultas Psikologi UGM, 1985.hlm. 26

Solichin Abdul Wahab, Analisa Kebijakan Publik, UMM Pres, Malang, 2008, hlm, 40-50.

Sumodiningrat, Konsep Good Governance, PT. Gramedia, Jakarta, 1999, hlm. 90-93.

Suwoto Mulyosudarmo, 1990, Kekuasaan dan Tanggung Jawab Presiden Republik Indonesia, Suatu Penelitian Segi-Segi Teoritik dan Yuridis Pertanggungjawaban Kekuasaan, Universitas Airlangga, Surabaya.

Tim penyusun, dkk, 2014, Panduan dan Pedoman Penulisan Skripsi Fakultas Hukum Univesitas Islam Indragiri, Alaf Riau, Pekanbaru.

Tim penyusun, 2015, Dewan Penelitian Pengupahan Nasional, Jakarta.

Tisnanta, Satria Prayoga, dkk, 2013, Hukum Tenaga Kerja, PKKPUU, Fakultas Hukum Universitas Lampung.

Titik Triwulan Tutik, 2010, Kontruksi Hukum Tata Negara Indonesia Pasca Amandemen UUD 1945, Kencana Prenada Media Group, Jakarta. 
Winarno Budi, 2002, Teori dan Proses Kebijakan Publik, CV. Media Pressindo, Jakarta.

\section{B. Peraturan-Perundang Undangan}

Undang-Undang Dasar Republik Indonesia Tahun 1945

Kitab Undang-Undang Hukum Perdata

Undang-Undang Nomor. 3 Tahun 1951 tentang Pernyataan Berlakunya Undang-Undang Pengawasan Perburuhan

Undang Undang Republik Indonesia Nomor. 13 Tahun 2000 tentang Tenaga Kerja

Undang-Undang Nomor. 13 tahun 2003 tentang ketenagakerjaan

Undang-Undang Nomor. 5 Tahun 2014 tentang Aparatur Sipil Negara.

Peraturan Pemerintah Nomor. 8 Tahun 1981 tentang Upah buruh

Peraturan Menteri Ketenagakerjaan Nomor 21 Tahun 2016 tentang Kebutuhan Hidup Layak

Peraturan Menteri Tenaga Kerja Dan Transmigrasi No Kep-226/Men/2000. Tentang perubahan peraturan menteri tenaga kerja nomor per-01/1999 tentang Upah Minimum

Peraturan Pemerintah Nomor. 48 Tahun 2005 tentang Pengangkatan Tenaga Honorer Menjadi Pegawai Negeri Sipil.

Permenakertrans 7/2013 serta Pasal 42 ayat (1) Peraturan Pemerintah Nomor 78 Tahun 2015 tentang Pengupahan

Keputusan Menteri Tenaga Kerja dan Transmigrasi Nomor. KEP226/MEN/2000 jangkauan wilayah upah minimum.

Surat Keputusan Gubernur Riau Nomor: Kpts. 1058/XI/2016 tentang Upah Minimum Kabupaten/Kota Se Provinsi Riau Tahun 2017. 


\section{Skripsi / Majalah}

Saprudin, Sosialisering Process Hukum Perburuhan dalam Aspek Kebijakan Pengupahan, Bagian Hukum Perdata, Fakultas Hukum Universitas Lambung Mangkurat, Banjarmasin, 2013.

Furqon Karim, 2001, Mencari Konsep Upah Minimum Bagi Pekerja, Hukum Ketenagakrjaan Pasca Reformasi, Majalah Suara Merdeka, 22 Desember,

\section{WEBSITE/INTERNET}

http/www.md ia.com.kamus indonesia online. Di akses pada tanggal 30 mei 2017, pukul 10.00 wib.

http://www.adhyepanrita.com.dasar hukum dan sejarahperkembangan.html, di akses pada tanggal 16 mei 2017, pukul 09.00 Wib.

http://www.bing.com.arti. penerapan, diakses pada tanggal 25 juni 2016, pukul 21:16 Wib

http://www.id/direktori-hukum/tata-cara-penyusunan-keputusan-gubernur diakses pada tanggal 25 juni 2016, pukul 21:16 Wib.

http://www.suarapembaruan.com/News/2008/04/07/sorotan/sorot01.htm. http:/www.id.m.wikipwdia.0rg.diakses pada tanggal, 16 Agustus 2016, Pukul,1:54

http://www.tipssukseskerja.wordpress.com/2013/12/02/peraturanmengenaibek erja-di-hari-libur pada tanggal 14 Januari 2017, pukul, 08.00 Wib. 


\section{E. Jurnal}

Ali Azhar, KMS Novyar Satriawan Fikri. 2020. Study Of Law Number 9 Off Regarding Freedom Of Speech In Publice, International Journal of Scientific \& Technology Research 9(1) : 4002-4006

Mulono Apriyanto, KMS. Novyar Satriawan Fikri, Vivi Arfiani Siregar, Jamri, Ali Azhar. 2020. Penyuluhan Tentang Peremajaan Kelapa Sawit Dan Legalitas Lahan Di Kecamatan Kempas Kabupaten Indragiri Hilir, JPM: Jurnal Pengabdian Masyarakat 1(1) : 1-16

KMS Novyar Satriawan Fikri, Ali Azhar. 2020. Academic Study Of District Formation South Indragiri. Progressive law review 2 (1) : 1-13

KMS Novyar Satriawan Fikri, Ali Azhar. 2020, Implementation of Discipline Policy for Civil Servants in Indragiri Hilir Regency Post Covid Pandemic 19, Proceedings of the 5th NA International Conference on Industrial Engineering and Operations Management.

Mulono Apriyanto, KMS Novyar Sariawan Fikri, Ali Azhar, 2020. Pendampingan Santri untuk Penurunan Tingkat Pelanggaran Lalu Lintas 1 (2) : 238-247.

KMS Novyar Satriawan Fikri, Herdiansyah, 2019. To Fighting The Covid 19 Virus In Indragiri Hilir. Jurnal Hukum DAS SOLLEN3 (2) : 23-45

KMS Novyar Satriawan Fikri, Fauziah Rahmah. 2018. Pelaksanaan Pemekaran Kecamatan Sentajo Raya Kabupaten Kuantan Singingi Menurut Peraturan Pemerintah Nomor 19 Tahun 2008 Tentang Kecamatan (Studi Terhadap Pasal 4 Huruf C dan D). Jurnal Hukum DAS SOLLEN 1 (4) : 1-10

\section{F. Hasil Wawancara}

Wawancara dengan direktur utama PDAM Tirta Indragiri Kabupaten Indragiri Hilir Pada Tanggal 5 agustus 2017 Pukul 09.00 Wib.

Wawancara dengan Kepala Bidang tenaga kerja dan trasmigrasi Kabupaten Indragiri Hilir Pada Tanggal 26 Mei 2017 Pukul 09.00 Wib.

Wawancara dengan Kepala Dinas tenaga kerja dan trasmigrasi Kabupaten Indragiri Hilir Pada Tanggal 26 Mei 2017 Pukul 09.00 Wib. 
